\title{
Strategic Supply Chain Management in the Era of Industry Revolution 4.0 :
}

\section{A Study of Textile Industry in Bali}

\author{
Juzer $^{(1)}$ \\ Gede Sri Darma ${ }^{(2)}$ \\ Director and Owner of Textile Industry in Bali ${ }^{(1)}$ \\ Universitas Pendidikan Nasional (2) \\ juzer_saify@yahoo.com ${ }^{(1)}$ \\ sridarma@undiknas.ac.id ${ }^{(2)}$
}

\begin{abstract}
The purpose of this research is to understand every problem inside textile company in Bali island. In this 4.0 industrial revolution era, a textile company is forced to pay attention in all aspect in order to run company strategy. All issues like goods supply certainty, price, product variety, credit sales, regulation and digital marketing has been discussed in detail to make the leader understood about the difficulty and challenge inside the company. This research uses qualitative method and using SWOT analysis which explain in complete ways how strength, weakness, opportunity and threat in every issue that occurred in a textile company in Bali island. The writer used interview technic in detail way to collect data from all the informant in a textile industry chain link. The final purpose of this research is to improve textile industry in Bali island based on accurate facts and data.
\end{abstract}

Keywords: Supply Chain Management; Strategic Business; Industrial Revolution 4.0 


\begin{abstract}
ABSTRAK
Tujuan utama penelitian ini adalah untuk mengetahui seluk beluk permasalahan dalam sebuah perusahaan textile di pulau Bali. Di era revolusi industri 4.0, perusahaan textile dituntut untuk selalu memerhatikan semua aspek dalam menjalankan strategi perusahaan. Permasalahan kepastian barang, harga barang, jenis produk, penjualan kredit, regulasi dan digital marketing dibahas secara detail untuk dapat membuat para pembaca memahami kesulitan dan tantangan yang dihadapi oleh perusahaan. Penelitian ini menggunakan metode kualitatif dan menggunakan analisis SWOT yang menjelaskan secara lengkap bagaimana kekuatan, kelemahan, peluang dan ancaman di setiap pembahasan masalah pada sebuah perusahaan textile di Bali. Pengumpulan data menggunakan teknik wawancara dalam mendapatkan data secara detail dari masing-masing narasumber yang terdapat pada mata rantai industri textile.Tujuan akhir dari penelitan ini adalah untuk memajukan industri textile di pulau Bali berdasarkan data-data dan fakta-fakta yang akurat.
\end{abstract}

Keywords: Supply Chain Management; Strategic Business; Industrial Revolution 4.0 


\section{PENDAHULUAN}

Pola penjualan perusahaan textile distributor maupun wholesaler saat ini telah mengalami perubahan di era revolusi industri 4.0. Seperti yang dipaparkan oleh Husein (2011:31); Bali dan Darma (2019); Darma (2019) bahwa strategi perusahaan dapat diklasifikasikan berdasarkan jenis perusahaan dan tingkatan tugas. Penjualan distributor maupun wholesaler saat ini lebih mudah dilakukan dengan adanya teknologi informasi seperti WhatsApp dan Instagram (Agung dan Darma, 2019); (Ferdiana dan Darma, 2019). Tidak seperti, sebelum era digital, dimana penjual harus menunjukkan sampel produk yang akan ditawarkan kepada pembeli. Proses pengiriman produk juga akan menjadi lebih cepat dikarenakan dengan adanya bantuan teknologi (Dewi dan Darma, 2019). Penjual dan pembeli dapat berkomunikasi secara langsung mengenai ketersediaan stok produk yang akan dikirim (Darma, 2018). Dahulu pemesanan barang oleh distributor ke perusahaan manufaktur adalah melalui telpon atau facsimile, akan tetapi sangatlah sulit dengan cara itu untuk menjelaskan detail warna ataupun motif pesanan, sehingga pihak distributor harus mendatangi perusahaan manufaktur untuk pemesanan barang (Kusnadi dan Darma, 2018). Sekarang di era revolusi industri 4.0 hal tersebut sudah sangat mudah dengan menggunakan email ataupun whatsapp atau wechat (Adnyasuari dan Darma, 2017) dan (Darma, 2006).

Di era digital revolusi industri 4.0 saat ini cara penjualan textile retail sudah banyak mengalami perubahan. Dahulu hanya dengan memajang produk di gerai dan menunggu pembeli datang berbelanja (Darma, 2012). Saat ini penjualan sudah lebih banyak dilakukan secara online, pembeli kebanyakan lebih memilih cara tersebut (Darma, dkk, 2019). Walaupun dalam pembelian textile itu diperlukan juga pengamatan langsung pada produk tersebut untuk mengetahui tekstur barang tersebut, tetapi pembeli sudah banyak yang mengabaikannya, dan juga walaupun pembeli datang ke toko retail untuk berbelanja kebanyakan menginginkan produk textile yang jadi dan siap pakai.

Instruksi gubernur Bali Nomor 2231 tahun 2018 yang berbunyi "Pelaksanaan Hari Penggunan Busana Adat Bali dan Bahasa Bali mulai dilaksanakan pada hari Kamis, tanggal 11 Oktober 2018”. Peraturan ini dikeluarkan untuk mewajibkan pemakaian pakaian adat Bali di sejumlah tempat seperti kantor pemerintahan, tempat pendidikan dan lain-lain, telah memberi suatu peluang yang sangat baik buat industri textile Bali dan sekaligus ancaman bagi pelaku textile yang tidak siap akan menyambut perubahan tersebut bisa tergeser pangsa pasarnya. 
Penelitian oleh Kuncoro Harto Widodo dan Erdi Ferdiansyah (2010) yang berjudul “Optimasi Kinerja Rantai Pasok Industri Textile Dan Produk Textile Indonesia Berdasarkan Simulasi Sistem Dinamis”. Hasil dari penelitian ini adalah diperolehnya 3 skenario optimasi, yaitu skenario jangka pendek, menengah dan jangka panjang. Skenario pertama dan merupakan usulan jangka pendek adalah usaha optimasi berupa minimasi atau pengurangan ketergantungan produk impor. Skenario kedua dan merupakan strategi jangka menengah adalah optimasi berupa maksimasi atau peningkatan ekspor TPT Indonesia. Skenario ketiga dan merupakan usulan jangka panjang adalah optimasi berupa minimasi impor serat kapas nasional.

Penelitian oleh Agus Widyarto (2012) yang berjudul "Peran Supply Chain Management Dalam Sistem Produksi Dan Operasi Perusahaan". Hasil penelitian menunjukkan secara umum manfaat Supply Chain Management bagi perusahaan adalah: pertama, Supply Chain Management secara fisik dapat mengkonversi bahan baku menjadi produk jadi dan mengantarkannya kepada konsumen akhir. Kedua, Supply Chain Management berfungsi sebagai mediasi pasar, yaitu memastikan apa yang dipasok oleh rantai suplai mencerminkan aspirasi pelanggan atau konsumen akhir tersebut.

Penelitian oleh Rusnandari Retno Cahyani (2014) yang berjudul "Pendekatan Supply Chain Management Untuk Meningkatkan Daya Saing Pada Bisnis Bunga Segar”. Hasil penelitian menunjukkan adanya manajemen rantai pasokan dalam perusahaan sangat memungkinkan tercapainya efisisensi bisnis bunga segar di pasar kembang surakarta untuk meningkatkan daya saing. Penerapan manajemen rantai pasokan sangat baik dan menguntungkan bagi bisnis, karena sistem ini memiliki kelebihan dimana mampu memanage aliran barang atau produk dalam rantai pasokan.

Penelitian oleh Dinul Akhiyar (2016) yang berjudul "Perancangan Aplikasi Supply Chain Management Pada Distribusi Ayam Potong PT. NUJ / MTS Dengan Menggunakan Metode Distributor Requirment Planning (DRP)". Hasil penelitian menunjukkan sesuai perkembangannya aplikasi Supply Chain Management yang terkomputerisasi sangatlah bermanfaat pada masa yang akan datang, hal ini telah terbukti pada saat sekarang ini banyak proses jual beli yang memakai sistem aplikasi SCM yang terkomputerisasi yang dapat memberikan informasi sehingga dapat memberikan pelayanan yang baik bagi pelanggan khususnya dibagian sistem distribusi.

Penelitian oleh Teddy Dwiyangtri dan Sarip Hidayatuloh (2012) yang berjudul "Implementasi Sistem Supply Chain Management (SCM) pada PT. Carrefour Indonesia". Hasil 
penelitian menunjukkan dalam melakukan usahanya, Carrefour menerapkan Warehouse Management System, yakni InfoLog, yang memungkinkan semua proses dalam rantai pasokan bisa diintegrasikan. Metode yang dipakai Carrefour untuk SCM ini dengan menerapkan proses just-in-time (JIT) di pusat distribusi (Distribution Center/DC), yang disebut Cross Dock. Hal ini bertujuan untuk mengefisienkan proses sehingga stok di pusat distribusi tidak diperlukan. Dengan adanya Cross Dock, maka peran DC (Distribution Center) semakin berjalan dengan baik.

Penelitian oleh Desi Ariani, Bambang Munas Dwiyanto (2013) yang berjudul "Analisis Pengaruh Supply Chain Management Terhadap Kinerja Perusahaan (Studi Pada Industri Kecil dan Menengah Makanan Olahan Khas Padang Sumatera Barat)". Hasil penelitian menunjukkan untuk meningkatkan kinerja perusahaan, perlu adanya strategi supply chain management yang diterapkan. Information sharing, long term relationship, cooperation, dan process integration merupakan bagian dari faktor-faktor yang mempengaruhi kinerja supply chain management.

Penelitian oleh Aldian Umbuh Tamu Ama, Eko Sediyono dan Adi Setiawan (2014) yang berjudul "Perancangan Sistem Informasi Manajement Rantai Pasok (Supply Chain Management) Untuk Distribusi Pangan Kabupaten Minahasa Tenggara”. Hasil penelitian menunjukkan perancangan sistem informasi manajemen rantai pasok memudahkan Dinas Ketahanan Pangan dalam penyimpanan data yang terpusat, khususnya untuk mengelola data hasil pangan, mengelola data petani, data koperasi dan data distribusi pangan.

Penelitian oleh Syamsu Ramadhan, Ratya Anindita, dan Suhartini (2014) yang berjudul "Kinerja Manajement Rantai Pasok Agroindustri Emping Jagung (Kasus di Kelurahan Pandanwangi, Kecamatan Blimbing, Kota Malang)". Hasil penelitian menunjukkan koordinasi antar pelaku dalam supply chain agroindustri emping jagung belum terjalin dengan baik terutama pada aliran informasi pada simpul agroindustri-pemasok dan pemasok-petani. Pemilihan pemasok yang tepat akan meningkatkan kinerja supply chain di masa mendatang dan untuk memilih pemasok yang potensial digunakan Analytical Hierarchy Process (AHP).

Penelitian oleh Dedy Panji Agustino (2015) yang berjudul "Perancangan Supply Chain Management Pada Sistem Pengelolaan Mice (Meetings Incentives Conferences Exhibitions) Di STMIK STIKOM Bali”. Hasil penelitian menunjukkan Perancangan sistem pengelolaan MICE di STIKOM Bali secara terkomputerisasi memang sangat dibutuhkan dalam rangka efisiensi waktu dan efektivitas sumber daya yang digunakan. 
Penelitian yang mengangkat permasalahan mengenai kinerja rantai pasok industri textile dilakukan oleh Agus Purnomo pada tahun 2015 dengan judul Analisis Kinerja Rantai Pasok Menggunakan Metode Supply Chain Operation Reference (Scor) Di Industri Textile Dan Produk Textile Sektor Industri Hilir (Studi kasus pada perusahaan garmen PT Alas Indah Remaja Bogor). Metode pengumpulan data yang digunakan dalam penelitian ini yaitu observasi dan wawancara dengan bagian pembelian, perencanaan produksi, dan pemasaran. Dalam penelitian ini didapatkan hasil kesimpulan yaitu peningkatan Kinerja Rantai Pasok perusahaan diprioritaskan pada proses source yaitu proses pengadaan barang maupun jasa untuk memenuhi permintaan. Proses yang tercakup meliputi penjadwalan pengiriman dari pemasok, menerima, mengecek, dan memberikan otorisasi pembayaran untuk barang yang dikirim pemasok, memilih pemasok, mengevaluasi kinerja pemasok. Supply chain management adalah hubungan timbal balik antara penyedia dan pelanggan untuk menyampaikan nilai-nilai yang sangat optimal kepada pelanggan dengan biaya yang cukup rendah namun memberikan keuntungan supply chain secara menyeluruh (Christopher, 2011:4). Proses source memiliki kinerja yang paling rendah. Upaya peningkatan kinerja dapat dilakukan dengan yaitu seleksi pemasok yang handal sehingga dapat menyediakan bahan baku secara tepat mutu, tepat jumlah, tepat waktu, tepat harga, tepat tempat, dan tepat kontrak. Dengan demikian dapat dibangun partnership jangka panjang dengan pemasok handal sehingga perusahaan lebih kompetitif dibandingkan pesaingnya.

Berdasarkan telaah pustaka tersebut dimana hasil temuan penelitian tersebut adalah proses source memiliki kinerja paling rendah di PT Alas Indah Remaja Bogor, maka peneliti tertarik untuk melakukan penelitian ulang pada daerah yang berbeda dan di dalam era revolusi industri 4.0. 


\section{Kerangka Konseptual}

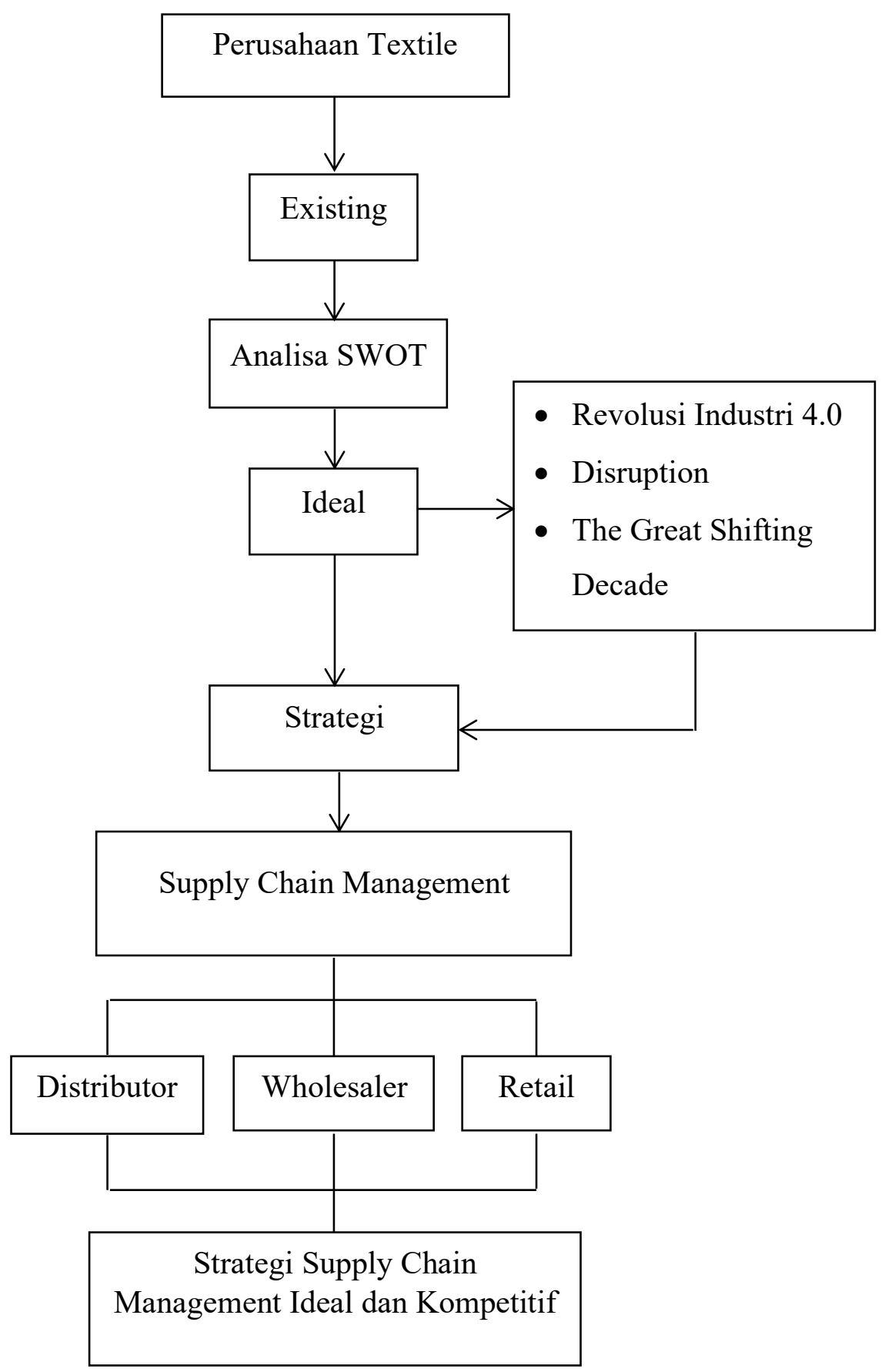

Gambar 1 Kerangka Konseptual

\section{METODE PENELITIAN}

Penelitian ini mengambil Saify Textile sebagai sumber data. Saify Textile yang berlokasi di Denpasar Bali dipilih karena merupakan perusahaan distributor kain terbesar yang bisa memberikan semua informasi yang dibutuhkan peneliti dalam rangka mengeksplorasi dunia industri textile di Bali. 
Penelitian menggunakan metode pendekatan kualitatif dengan metode analisis deskriptif yang dapat diartikan sebagai metode penelitian yang berlandaskan pada filsafat enterpretif digunakan untuk meneliti pada kondisi obyek yang alamiah, (sebagai lawannya adalah eksperimen) dimana peneliti sebagai instrumen kunci, teknik pengumpulan data dilakukan secara trianggulasi (gabungan), analisis data bersifat induktif atau kualitatif, dan hasil penelitian kualitatif lebih menekankan makna dari pada generalisasi (Darma, 2004).

Dalam penelitian ini teknik sampling yang digunakan yaitu purposive sampling. Menurut Sugiyono (2016) purposive sampling adalah teknik pengambilan sampel sumber data dengan pertimbangan tertentu. Alasan menggunakan teknik Purposive Sampling adalah karena tidak semua sampel memiliki kriteria yang sesuai dengan fenomena yang diteliti. Oleh karena itu, penulis memilih teknik Purposive Sampling yang menetapkan pertimbangan-pertimbangan atau kriteria-kriteria tertentu yang harus dipenuhi oleh sampel-sampel yang digunakan dalam penelitian ini.

Penulis juga mengumpulkan data dengan melakukan wawanara dengan para informan yang berhubungan langsung dengan perusahaan. Face to face interview (wawancara berhadaphadapan) dilakukan terhadap enam partisipan yang diharapkan penulis bisa mendapatkan data yang solid.

\section{PEMBAHASAN}

Dari penelitian yang dibuat muncullah data dan informasi yang perlu diuraikan secara mendalam beberapa masalah yang akan dibahas oleh peneliti adalah sebagai berikut:

A. Kepastian barang yang merupakan salah satu kunci sukses perusahaan Saify dalam hal memberikan pelayanan kepada para pelanggannya. Hal tersebut didukung oleh pendapat Heizer and Render (2011:7) dan Darma (2019) bahwa, desain rantai pasokan, perencanaan, dan keputusan operasi memberikan peranan yang penting dalam menentukan keberhasilan atau kegagalan sebuah organisasi. Pergerakan pasar yang sangat cepat membuat perusahaan harus selalu siap sedia dalam penyediaan barang karena pelanggan Saify Textile juga mempunyai konsumen yang menuntut selalu tersedianya barang. Kepastian barang sangat penting untuk bisa tetap menjaga para pelanggan untuk tidak berpindah ke distributor lainnya (Darma, 2012). Para kompetitor Saify Textile selalu mengintai dan siap mengambil para pelanggan yang tidak puas akan pelayanan perusahaan. Penekanan dalam hal kepastian barang sangat krusial dan 
penting untuk selalu dilakukan oleh perusahaan. Memastikan adanya supply barang akan membuat rantai perdagangan berjalan dengan dinamis dan berkesinambungan.

B. Penentuan harga barang merupakan hal yang sangat sensitif baik bagi perusahaan maupun konsumennya (Darma, 2012). Penentuan harga barang yang sesuai akan membuat supply chain berjalan dengan baik. Penentuan harga barang sangat menentukan keberhasilan perusahaan dalam menjual produknya. Hal ini karena disebabkan demand (permintaan) yang besar yang mengakibatkan munculnya persaingan bebas antar sesama penjual (Dewi dan Darma, 2019). Persaingan bisnis yang saat ini semakin ketat dikarenakan dampak globalisasi dari diberlakukanya era perdagangan bebas yang kini telah menggeser paradigma bisnis dari Comparative Advantage menjadi Competitive Advantage, yang memaksa kegiatan bisnis atau perusahaan memilih strategi yang tepat (Giovanna dan Darma, 2019). Strategi tersebut antara lain perusahaan berada dalam posisi strategis dan bisa beradaptasi dengan lingkungan yang terus berubah (Krisnamurti dan Darma, 2015). Strategi bisnis, dalam suatu kata, adalah mengenai keunggulan kompetitif. Hal ini berlaku prinsip going concern yang secara umum merupakan tujuan didirikanya suatu entitas bisnis (Ohmae 2011:10; Agung dan Darma, 2019). Perangkat informasi yang lebih luas ini setidaknya harus memenuhi dua syarat (Hansen and Mowen, 2011). Pertama, perangkat informasi ini harus mencakup informasi mengenai lingkungan perusahaan dan lingkungan kerja perusahaan. Kedua, perangkat informasi tersebut juga harus prospektif dan karenanya harus memberikan pandangan mengenai periode dan kegiatan di masa-masa mendatang. Dengan demikian supply chain manajemen dapat digunakan sebagai salah satu alat analisis manajemen perusahaan untuk pengambilan keputusan strategis dalam menghadapi persaingan bisnis yang semakin ketat.

C. Peneliti membahas tentang jenis-jenis produk Jenis produk baju jadi mempunyai porsi terbesar sebanyak 70\% sedangkan 30\% lainnya adalah bahan kain. Penelitian lebih memfokuskan pada produk bahan kain. Saify Textile menjadi faktor penting dalam kebutuhan tersebut sebagai supplier bahan baku kepada produsen-produsen baju jadi. Selain memenuhi kebutuhan di sektor pariwisata, Saify Textile juga memenuhi kebutuhan pasar lokal juga sangat besar yaitu pakaian adat Bali. Masyarakat Bali yang terkenal sangat religius dalam menjalankan ibadah agamanya, membutuhkan barangbarang perlengkapan untuk menunjang ibadahnya. Salah satunya adalah pakaian khas adat Bali yang selalu dipakai setiap melakukan upacara-upacara keagamaan. 
Masyarakat Bali yang mayoritas beragama Hindu membutuhkan supply baju jadi maupun bahan kain yang sangat besar.

D. Penjualan kredit juga diangkat peneliti sebagai salah satu pembahasan yang tidak kalah penting, peneliti mengetahui dari sumber informan yang diperoleh bahwa penjualan di perusahaan Saify lebih banyak dilakukan dengan cara kredit. Peneliti membahas tentang arti penjualan kredit, beserta resiko-resiko yang dapat terjadi. Saify saat ini melayani penjualan kredit dengan tempo dua sampai enam bulan. Hal itu sering kali menyebabkan terjadinya kredit macet dari pelanggan. Untuk itu diperlukan evaluasi baik dari cara pemberian kredit maupun seleksi yang ketat dalam memilih pelanggan baru. Sebagai contoh dari pemberian kredit adalah memotong tempo dari dua sampai enam bulan menjadi maksimal dua bulan. Dengan begitu diharapkan akan mengurangi resiko terjadinya kredit macet. Salah satu penyebab kredit macet adalah adanya pelanggan yang tidak mampu membaca pergerakan tren pasar jika terjadi penumpukan stok barang yang tidak laku akibat terjadinya perubahan tren. Perlu dilakukan juga adalah tetap memantau kinerja, penjualan dan pembayaran dari pelanggan lama. Hal ini dilakukan supaya tidak terjadi problem potensial tentang kredit macet dari para pelanggan lama.

E. Munculnya regulasi baru yang dikeluarkan oleh gubernur Bali pada tahun 2018 menyebabkan beberapa hal yang bersifat positif maupun negatif. Peneliti melihat perlunya pembahasan yang mendalam tentang regulasi karena dinilai signifikan. Regulasi tersebut juga diikuti dengan instruksi pemakaian busana adat Bali yang lebih sopan dan tertutup Instruksi yang menggambarkan bukti toleransi tinggi antar umat beragama ini juga disertai dengan efek yang tidak menguntungkan bagi pemain dirantai retail dikarenakan penggunaan jenis kain brokat tidak lagi sepopuler dulu. Bahan brokat yang transparan menyebabkan tidak digunakannya lagi sebagai bahan dasar busana adat Bali. Pemain retail yang mengkhususkan diri dalam bidang kain brokat diharuskan lebih bisa berinovasi dan beralih ke bahan kain yang dimaksud oleh instruksi gubernur tersebut. Berita terbaiknya adalah kain diamond crep sebagai alternatif bahan busana adat Bali yang lebih sopan mengalami lonjakan penjualan yang sangat signifikan. Untuk itu Saify Textile mendatangkan jenis bahan kain ini untuk memenuhi kebutuhan para konsumennya. Tersedianya bahan kain ini dengan variasi warna beserta kuantitas yang besar adalah poin sebelumnya yang dimaksud oleh penulis yaitu kepastian barang. 
F. Terakhir dan juga merupakan pembahasan yang tidak kalah penting adalah peran digital marketing dalam era revolusi industri 4.0. Menurut Setyaningsih \& Vanda, 2018, disruptif innovation bermunculan dengan inovasi baru yang berhasil mengganti, mengubah, memperbarui model bisnis, aturan main, struktur pada era disruptive innovation merupakan keberhasilan mentransformasi suatu sistem atau pasar eksisting dengan memperkenalkan kepraktisan, kemudahan akses, kenyamanan dan biaya yang ekonomisMarketing yang mempunyai peran penting dalam menentukan sukses tidaknya suatu perusahaan telah mengalami perubahan-perubahan inovasi dalam fungsinya dan alat-alat penunjangnya. Banyaknya pabrik textile dan jenis hasil kain membuat banyaknya ragam dalam hasil akhir pembuatan kain. Digital marketing dalam fungsinya selain untuk media promosi juga akan menarik calon pembeli untuk datang melihat langsung barang-barang yang diinginkan di toko tersebut. Hal ini juga merupakan keuntungan dan strategi toko untuk membuat calon pembeli tersebut menginginkan atau membeli barang lain yang juga tersedia di toko tersebut.

Strategi didefinisikan sebagai suatu proses penentuan rencana para pemimpin puncak yang berfokus pada tujuan jangka panjang organisasi, disertai penyusunan suatu cara atau upaya bagaimana agar tujuan tersebut dapat dicapai (Solihin, 2012:31; Kanten dan Darma, 2017). Dari hasil penelitian yang dilakukan di Saify Textile diperoleh bahwa Saify Textile sudah menerapkan strategi supply chain manajemen yang tepat untuk mendapatkan kepastian barang dari supplier maupun penyaluran barang ke pelanggan dan juga memperoleh harga barang yang kompetitif baik dari pemberian harga oleh supplier maupun memberikan harga ke pelanggan. Saify sudah membentuk jaringan yang kuat ke supplier dengan bekerja sama dengan supplier yang tetap dan juga ke para pelanggan tetap yang sudah bekerja sama selama lebih dari sepuluh tahun. Saify mendatangkan barang dengan kuantitas besar sehingga bisa mendapatkan harga pokok yang lebih murah agar bisa bersaing dan lebih unggul dari pada para kompetitor. Saify juga memberikan plafon kredit tinggi kepada para pelanggan utamanya sehingga mereka bisa dan berani mengambil barang dalam jumlah besar. Saify mulai merubah pola marketing konvensionalnya menjadi pola digital marketing untuk mempromosikan dan memasarkan produknya. Marketing konvensional yaitu cara memasarkan barang dengan membawa sample barang ke masing-masing pelanggan sedangkan digital marketing adalah mempromosikan barang dengan memposting desain-desain atau warna-warna baru di sosial media seperti Facebook dan Instagram ataupun memasarkan barang melalui WhatsApp. Saify 
juga menyadari bahwa jaringan rantai pasoknya belum merata ke semua kabupaten di Bali sehingga dengan digital marketing diharapkan dapat memudahkan penyebaran barang ke seluruh Bali. Saify juga berupaya mengurangi resiko hutang macet dari penjualan kredit dengan cara melakukan seleksi yang lebih ketat dalam memilih pelanggan baru dan menjaga pelanggan lama dari kemungkinan terjadinya kredit macet dengan cara memantau kinerja dan pembayaran dari pelanggan lama. Seluruh hasil pengamatan diatas merupakan kajian dari analisis SWOT yang telah dijabarkan oleh peneliti sesuai dengan Freddy Rangkuti (2013); Darma (2018), analisis SWOT diartikan sebagai: “analisa yang didasarkan pada logika yang dapat memaksimalkan kekuatan (strengths) dan peluang (opportunities), namun secara bersamaan dapat meminimalkan kelemahan (weaknesses) dan ancaman (threats)". Sedangkan menurut Robinson (2011) analisis SWOT merupakan salah satu instrumen analisis lingkungan internal dan eksternal perusahaan yang dikenal luas.

\section{PENUTUP}

Dari penelitian yang dilakukan di perusahaan Saify Textile dalam kaitannya penerapan strategic supply chain management pada era revolusi industri 4.0 bertujuan untuk mengetahui strategi manajemen rantai pasok (supply chain) yang ideal dilakukan di perusahaan textile di era revolusi industri 4.0 dibandingkan dengan strategi yang lain dan untuk mengetahui cara perusahaan textile meraih keunggulan kompetitif melalui managemen supply chain yang ideal di era revolusi industri 4.0.

Bahwa terdapat keunggulan dan kelemahan di perusahaan Saify Textile membuat peneliti memberikan penjabaran secara mendalam di segala aspek dengan menggunakan analisis SWOT. Bahwa perusahaan telah menerapkan strategi supply chain management tidak membuat perusahaan telah mencapai hasil yang maksimal. masih perlunya peningkatanpeningkatan dan penerapan-penerapan teknologi terbaru untuk meningkatkan performa perusahaan.

Peneliti menyadari dengan keterbatasan yang dimiliki oleh peneliti yakni tidak dapat meneliti seluruh masalah yang terjadi di Saify Textile. Maka peneliti berharap dengan rekomendasi ini, dapat memberikan panduan untuk penelitian mendatang yang berkaitan dengan penelitian ini, antara lain penelitian di industri garment yang berbeda secara managemen dan kegiatan operasional dibandingkan dengan perusahaan distributor dibandingkan dengan perusahaan distributor textile. Struktur organisasi, marketing dan supply chain yang berbeda dapat dijadikan ide untuk peneliti berikutnya dan rekomendasi lainnya 
yaitu melakukan penelitan di sektor retail karena merupakan mata rantai terakhir yang bersentuhan langsung dengan end user. Sektor retail yang terdiri dari toko, pasar tradisional dan online shop layak dijadikan penelitian selanjutnya. 


\section{DAFTAR PUSTAKA}

Adnyasuari, P.A.S., and Darma, G.S. (2017). Technology Acceptance Model dan ESatisfaction in Mobile Banking, Jurnal Manajemen \& Bisnis, 14 (2): 1-12.

Agung, N.F.A., and Darma, G.S. (2019). Opportunities and Challenges of Instagram Algorithm in Improving Competitive Advantage, International Journal of Innovative Science and Research Technology, 4 (1): 743-747.

Agustino, D.P. (2015). Perancangan Supply Chain Management Pada Sistem Pengelolaan Mice (Meetings Incentives Conferences Exhibitions) Di STMIK STIKOM Bali, Konferensi Nasional Sistem \& Informatika.

Ama, A.U.T., Sediyono, E., dan Setiawan, A. (2014). Perancangan Sistem Informasi Manajement Rantai Pasok (Supply Chain Management) Untuk Distribusi Pangan Kabupaten Minahasa Tenggara, Prosiding Seminar Ilmiah Nasional Komputer dan Sistem Intelijen Vol. 8 Oktober.

Ariani, D., Dwiyanto, B.M. (2013). Analisis Pengaruh Supply Chain Management Terhadap Kinerja Perusahaan (Studi Pada Industri Kecil dan Menengah Makanan Olahan Khas Padang Sumatera Barat), Diponegoro Journal of Management.

Akhiyar, D. (2016). Perancangan Aplikasi Supply Chain Management Pada Distribusi Ayam Potong PT. NUJ / MTS Dengan Menggunakan Metode Distributor Requirment Planning (DRP), Jurnal Sains dan Teknologi, 16 (2): 114-186.

Bali, I.N.A.P., and Darma, G.S. (2019). Menguji Kesiapan Pengelolaan Desa Berbasis Manajemen Modern Guna Menghadapi Era Revolusi Industri 4.0, Jurnal Manajemen \& Bisnis, 16 (2): 1-13.

Christopher, M. (2011). Logistics and Supply Chain Management Fourth Edition. London: Prentice Hall.

Darma, G.S. (2004). Qualitative and Quantitative Data in Management Research: A Study of the Banking Industry, Jurnal Ekonomi \& Bisnis, 16 (2): 107-118.

Darma, G.S. (2006). Optimalisasi Penggunaan Teknologi Informasi dan Kinerja Organisasi. Denpasar: Undiknas Press.

Darma, G.S. (2012). 100 Konsultasi Praktis Strategi Bisnis. Denpasar: Undiknas Press.

Darma, G.S. (2018). Seuntai Pesan, Menjawab Zaman. Indonesia: Pustaka Larasan Press.

Darma, G.S. (2019). Kacamata Media, Kesuksesan Bersyarat. Indonesia: Pustaka Larasan Press. 
Darma, G.S., Apollo, A., Rusmanda, G., and Umar, Y. (2019). Digital Education 4.0. Indonesia: Cakra Media Utama Press.

Darma, G.S. (2003). Managing the Use of E-Mail: A Survey of the Customer-View at Global Gossips Internet Course \& Café, Jurnal Ekonomi \& Bisnis, 15 (2): 1-10.

Darma, G.S. (1998). Information Technology, Hotel Performance, User Performance and User Satisfaction as an Intervening Variable, Southern Cross University, Lismore New South Wales Australia.

Dewi, M.V.K., and Darma, G.S. (2019). The Role of Marketing \& Competitive Intelligence in Industrial Revolution 4.0, Jurnal Manajemen \& Bisnis, 16 (1): 1-12.

Dewi, N.K.Y.W., and Darma, G.S. (2019). Strategi Investasi \& Manajemen Resiko Rumah Sakit Swasta di Bali, Jurnal Manajemen \& Bisnis, 16 (2): 110-127.

Dwiyangtri, T., dan Hidayatuloh, S. (2012). Implementasi Sistem Supply Chain Management (SCM) pada PT. Carrefour Indonesia, Jurnal Sistem Informasi: 1-6.

Ferdiana, A.M.K., and Darma, G.S. (2019). Understanding Fintech Through Go-Pay, International Journal of Innovative Science and Research Technology, 4 (2): 257-260.

Giovanna, N., and Darma, G.S. (2019). Scanlated vs. Physical Japanese Comic Manga, International Journal of Innovative Science and Research Technology, 4 (1): 630-636. Hansen and Mowen. (2011). Management Biaya; Akuntansi dan Pengendalian, alih bahasa Tim Salemba Empat. Jakarta: Salemba Empat.

Heizer, R.P. (2011). Supply Chain Management: Strategy, Planning and Operasion, 2nd or 3rd Edition. New Jersey: Pearson Prentice Hall.

Kanten, I.K., and Darma, G.S. (2017). Consumer Behaviour, Marketing Strategy, Customer Satisfaction, and Business Performance, Jurnal Manajemen \& Bisnis, 14 (2): 143-165. Krisnamurti, M.B., and Darma, G.S. (2015). Strategi Diferensiasi Produk dan Jasa di Industri Digital Printing, Jurnal Manajemen \& Bisnis, 12 (1): 122-139.

Kusnadi, D.S., and Darma, G.S. (2018). Menakar Implementasi Green Marketing Pada Usaha Kecil Menengah, Jurnal Manajemen \& Bisnis, 15 (1): 1-18.

Lo, B., and Darma, G.S. (2000). Employee Perception of the Impact of Information Technology Investment in Organisations: A Survey of the Hotel Industry, Australasian Journal of Information Systems, 7 (2): 32-51.

Ohmae, K. (2011). The Borderless World, rev ed: Power and Strategy in the Interlinked Economy. Harper Collins. 
Purnomo, A. (2015). Analisis Kinerja Rantai Pasok Menggunakan Metode Supply Chain Operation Reference (SCOR) di Industri Textile dan Produk Textile Sektor Industri Hilir (Studi kasus pada perusahaan garmen PT Alas Indah Remaja Bogor).

Rangkuti, F. (2013). Analisis SWOT Teknik Membedah Kasus Bisnis. Jakarta: Gramedia Pustaka Utama.

Rusnandari, R. C. (2014). Pendekatan Supply Chain Management Untuk Meningkatkan Daya Saing Pada Bisnis Bunga Segar, Ekonomi Bisnis \& Kewirausahaan, 3 (1).

Robinson, P. (2011). Manajemen Strategik Formulasi, Implementasi, dan Pengendalian. Jakarta: Bina Rupa Aksara.

Ramadhan, S. (2014). Ratya Anindita, dan Suhartini, "Kinerja Manajement Rantai Pasok Agroindustri Emping Jagung (Kasus di Kelurahan Pandanwangi, Kecamatan Blimbing, Kota Malang), Habitat, 25 (3).

Setyaningsih, E. D., \& Vanda, L. (2018). Analisis SWOT Financial Teknologi Pada Kualitas Layanan Perbankan di Era Disruptif.Seminar Nasional Inovasi Dan Tren (SNIT).

Solihin, I. (2012). Desain Penelitian Manajemen Strategik. Jakarta: Rajawali Press.

Sugiyono. (2013). Metode Penelitian Pendidikan Pendekatan Kuantitatif, Kualitatif, dan R\&D. Bandung: Alfabeta.

Sugiyono. (2016). Metode Penelitian Kuantitatif Kualitatif dan Kombinasi (Mixed Methods). Bandung: Alfabeta.

Umar, H. (2011). Riset Pemasaran dan Perilaku Konsumen.Cetakan kedua. Jakarta: Gramedia. Pustaka Utama.

Widyarto, A. (2012). Peran Supply Chain Management Dalam Sistem Produksi dan Operasi Perusahaan, Jurnal Manajemen dan Bisnis, 16 (2).

Widodo, K. H., dan Erdi Ferdiansyah. (2010). Optimasi Kinerja Rantai Pasok Industri Textile Dan Produk Textile Indonesia Berdasarkan Simulasi Sistem Dinamis, Jurnal Agritech, 30 (1). 